\title{
Incretin combination therapy for the treatment of non-alcoholic steatohepatitis
}

\author{
Aimo Kannt ${ }^{1,2,}$, Andreas Nygaard Madsen ${ }^{3}$, Claire Kammermeier ${ }^{1}$, Ralf Elvert ${ }^{1}$, Martin Bossart ${ }^{1}$, \\ Torsten Haack ${ }^{1}$, Andreas Evers ${ }^{1}$, Katrin Lorenz ${ }^{1}$, Corinne Rocher ${ }^{4}$, Zsolt Böcskei ${ }^{4}$, Jean-Claude \\ Guillemot ${ }^{4}$, Vincent Mikol ${ }^{4}$, Francois Pattou ${ }^{5}$, Bart Staels ${ }^{5}$, Michael Wagner ${ }^{1, *}$
}

\author{
${ }^{1}$ Sanofi Research and Development, D-65926 Frankfurt, Germany \\ ${ }^{2}$ Experimental Pharmacology, Medical Faculty Mannheim, University of Heidelberg, D-68167 \\ Mannheim, Germany \\ ${ }^{3}$ Gubra, 2970 Horsholm, Denmark \\ ${ }^{4}$ Sanofi Research and Development, 91385 Chilly-Mazarin Cedex, France \\ ${ }^{5}$ Université de Lille, Inserm, CHU Lille, European Genomic Institute for Diabetes, 59000 Lille, France \\ *Corresponding authors
}

\begin{abstract}
Aims: Agonists to the glucagon-like peptide 1 receptor (GLP1R) agonists and dual agonists targeting GLP1R and the glucagon receptor (GCGR) or the Glucose-dependent insulinotropic peptide receptor (GIPR) are currently being developed for the treatment of non-alcoholic steatohepatitis (NASH). We have tested specific mono-agonists to these three receptors individually and in combination in a mouse model of diet-induced NASH and fibrosis, to decipher the contribution of their activities and potential additive effects on improving systemic and hepatic metabolism.

Materials and methods: Advanced NASH was induced by pre-feeding C57BL/6J mice a diet rich in fat, sucrose and cholesterol for 36 weeks. This was followed by eight weeks of treatment with the

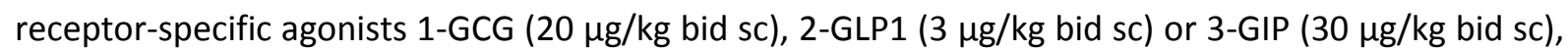
or the dual $(1+2)$ or triple $(1+2+3)$ combinations thereof. A dual GLP1R/GCGR agonistic peptide, 4dual-GLP1/GCGR (30 $\mu \mathrm{g} / \mathrm{kg}$ bid sc), and liraglutide (100 $\mu \mathrm{g} / \mathrm{kg}$ bid sc) were included as references.

Results: Whereas 1-GCG and 3-GIP alone, at the selected low dose, did not influence body weight, liver lipids and histology, their combination with 2-GLP1 provided additional weight loss, reduction in liver triglycerides and improvement in histological NAFLD activity score (NAS). In addition, there was a trend to further reduction in markers of hepatic inflammation and fibrosis. Notably, compared to
\end{abstract}


high-dose liraglutide, 4-dual-GLP1R/GCG as well as the dual and triple combinations of selective mono-agonists demonstrated stronger improvement in NAS at the same extent of body weight loss.

Conclusions: GCGR and GIPR agonism provide additional, body weight-independent improvement in a murine model of advanced NASH with fibrosis on top of GLP1R agonism.

\section{Introduction}

Non-alcoholic fatty liver disease (NAFLD) covers a spectrum of hepatic abnormalities ranging from simple steatosis to non-alcoholic steatohepatitis (NASH) and liver fibrosis. Fatty liver is very common, with an estimated global prevalence of approximately $25 \%$, and strongly associated with other systemic conditions such as obesity, diabetes and dyslipidemia. ${ }^{1}$ Progression to NASH and especially to NASH with advanced fibrosis is a strong risk factor for the development of cirrhosis and hepatocellular carcinoma, has been linked to increased overall and liver-related mortality, and is becoming the leading cause of liver transplantation. ${ }^{2,3,4,5,6}$ From a pathophysiological perspective, fat and triglyceride accumulation in the liver, hepatic and adipose tissue insulin resistance, inflammation as well lipotoxicity and oxidative stress are involved in the development of NAFLD. At present there are no approved pharmacological therapies available to treat NAFLD/NASH. Lifestyle intervention focusing on weight loss is regarded as first line therapy. ${ }^{7}$ Thus, novel treatment options for NAFLD/NASH are highly warranted.

Amongst the various approaches which are being investigated to treat NAFLD/NASH are agonists of the glucagon-like peptide 1 receptor (GLP1R) agonists or GLP-1-based multi-agonists as they have been shown to produce significant and sustained weight loss as well as elicit favorable metabolic effects. ${ }^{8,9}$ For example, treatment of patients with biopsy-confirmed NASH with liraglutide, a once daily GLP1R agonist, over 48 weeks at a dose of $1.8 \mathrm{mg} /$ day (LEAN study) led to a resolution of NASH in $39 \%$ of the treated patients as well as to reduced worsening of fibrosis. ${ }^{10}$

Unimolecular dual or triple agonists activating besides the GLP-R also the glucagon receptor (GCGR) or/and the glucose-dependent insulinotropic peptide receptor (GIPR) are emerging as a promising class of next generation drug molecules offering significantly improved metabolic effects and weight loss. ${ }^{11}$ Besides their pronounced effects on glycemic control and body weight, dual GLP1/GCGR agonists were shown to improve lipid metabolism and hepatic steatosis in mice with diet-induced obesity (DIO). ${ }^{12}$ When studied in non-human primates, treatment with an activity-balanced, lipidated dual GLP1R/GCGR agonist, MEDI0382, led to significant hepatic fat reduction, which was also seen in human clinical studies. ${ }^{13,14}$ MEDI0382 is currently under advanced clinical development for treatment of NAFLD/NASH. (clinicaltrials.gov; NCT04019561) 
Likewise, unimolecular dual GLP-1R /GIPR agonists as well as triple GLP-1R/GIPR/GCGR agonists have been shown to improve glycemic control and weight loss in DIO mice accompanied by improved liver function and hepatic steatosis. ${ }^{15,16}$

However, very little is known on the effects of these multi-incretin approaches in models of obesity and insulin resistance in combination with manifest NASH and advanced fibrosis. Also, the contribution of their individual components - GLP1R, GCGR and GIPR agonism - on hepatic and metabolic disease in the setting of NASH has not been thoroughly investigated. In the absence of such systematic studies, we have designed acylated, selective GLP-1R, GCGR and GIPR agonists as tool compounds and studied them alone and in combination in a mouse model of diet-induced, biopsy-confirmed advanced NASH and fibrosis to better understand their individual contribution and potential additive effects on improving systemic and hepatic metabolism. 


\section{Methods}

\section{Animals and experimental design}

The peptides were investigated in a mouse model of diet-induced obesity, NASH and fibrosis (DIONASH model) as described. ${ }^{17}$ All animal experiments were conducted according to the international principles for care and use of laboratory animals and were covered by personal licenses for Jacob Jelsing (2013-15-2934-00784 and 2015-15-0201-00518) issued by the Danish committee for animal research.

Male C57BL/6J mice (5 weeks old) obtained from JanVier (LanVier Labs, France) were placed on either standard rodent chow (Altromin 1324, Brogaarden, Denmark) or AMLN diet (D09100301, Research Diet, United States). AMLN diet is a NASH-inducing diet rich in fat (40\%, including $18 \%$ trans-fat), carbohydrates (40\%, including $20 \%$ fructose) and cholesterol (2 \%) as previously described. ${ }^{18}$ After 33 weeks on these diets, a baseline liver biopsy was conducted for histological assessment of individual fibrosis and steatosis staging, as described. ${ }^{17}$ A total of 96 mice $(n=12$ per treatment group) were randomized and stratified according to body weight and liver Col1A1 quantification. Ten mice on chow diet were included as controls. Treatment commenced 36 weeks after starting on the diets and lasted for eight weeks with all animals remaining on the same diet as in the pre-treatment phase. At the end of the intervention, animals were euthanized and liver tissue and serum samples were collected.

Tested compounds and doses are summarized in table 1. All compounds were administered twice daily by subcutaneous injection using phosphate-buffered saline as vehicle.

Methods used for body weight and body composition analysis, blood sampling, plasma biochemistry and liver tissue biochemistry are detailed in Supplemental Information.

\section{Histology assessment}

Baseline liver biopsy and terminal samples were collected from the left lateral lobe (about 50-100 mg at baseline and $200 \mathrm{mg}$ at the end) and fixed overnight in $4 \%$ paraformaldehyde. Liver tissue was paraffin embedded and sectioned ( $3 \mu \mathrm{m}$ thickness). Sections were stained with Hematoxylin and Eosin and Sirius Red to assess hepatic steatosis and fibrosis respectively, followed by analysis with Visiomorph software (Visiopharm, Denmark). Col1a1 and galectin-3 were assessed using IHC staining. A blinded to the study pathologist performed the histological assessment and scoring. NAFLD activity score (NAS) (steatosis/inflammation/ballooning degeneration) and fibrosis stage were quantified applying the criteria proposed by Kleiner et al. ${ }^{19}$ 


\section{Hepatic gene expression changes}

Liver tissue was harvested from the left lateral lobe, stabilized overnight in RNAlater $^{\circledR}$ solution (Merck KGaA, Darmstadt, Germany) and stored at $-80^{\circ} \mathrm{C}$. Total RNA isolation was performed with the miRNeasy kit following the instructions of the manufacturer (QIAGEN GmbH, Hilden, Germany). RNA was quantified with an Agilent RNA 6000 Nano kit using an Agilent 2100 Bioanalyzer (Agilent Technologies Inc, Waldbronn, Germany). Gene expression was quantified using droplet digital PCR or qRT-PCR analysis as described in Supplemental Information.

\section{Statistical analysis}

Data are presented as mean \pm standard error of the mean (SEM). Statistical significance was evaluated using Dunnett's test one-factor linear model for body composition, blood and liver biochemistry. T-test was used for the comparison of differences of gene expression between the groups. $\mathrm{P}<0.05$ was set as the statistical significance level.

\section{Results}

\section{Test compounds}

For the systematic study of incretin hormone analogs and their combination in the described NASH animal model, specific mono-agonists of the GLP1R, GCGR and the GIPR were generated. In addition, an earlier described dual GLP1R/GCGR agonist ${ }^{20}$ was used as well as Liraglutide as GLP1 standard for comparison. Compounds 1-GCG, 2-GLP1 and 3-GIP were all designed based on the exendin-4 sequence using acylation with either palmitic acid or stearic acid to prolong their half-life, similar to liraglutide (table 1a). In mice, 1-GCG is an equipotent GCGR agonist compared to glucagon itself with a much better selectivity profile towards the GLP1R (> 300-fold). 2-GLP1 \& 3-GIP were at least 3000fold selective for their corresponding receptor (table $1 b) .{ }^{21,22}$ In mice, the dual agonist 4-dualGLP1/GCG was 10-fold more active at the GLP1R compared to the GCGR. All selected compounds had reasonable pharmacokinetic properties in mice with half-lifes of 2.5-4.1 h after subcutaneous administration (table $1 c$ ). In order to guarantee full daily coverage in our DIO-NASH model the compounds were dosed twice daily (b.i.d.) by subcutaneous administration. The doses selected for compounds 1-GCG, 2-GLP1, 3-GIP were $20 \mu \mathrm{g} / \mathrm{kg}, 3 \mu \mathrm{g} / \mathrm{kg}$ and $30 \mu \mathrm{g} / \mathrm{kg}$ b.i.d, respectively. These comparably low doses were selected to allow for the identification of additive or synergistic activity when given in combination at the same individual doses. Liraglutide as a reference GLP-1R agonist 
was administered at $100 \mu \mathrm{g} / \mathrm{kg}$ twice daily to provide near-maximal effects that can be achieved with a selective GLP1R agonist. The dose of compound 4-dual-GLP1/GCG was chosen as $30 \mu \mathrm{g} / \mathrm{kg}$ b.i.d. to achieve an extent of weight loss which is similar to liraglutide at $100 \mu \mathrm{g} / \mathrm{kg}$ b.i.d.

\section{Body composition and food intake, blood glucose}

Figure 1 a shows the relative change in body weight over the treatment period of eight weeks. Average body weight at the onset of treatment was 36.1 gram ( \pm 0.3 gram SEM) without significant differences between treatment groups, compared to $31.1 \pm 0.4$ gram for the chow control mice. Whereas vehicle-treated mice gained about $3 \%$ over the treatment period, body weight remained constant for mice treated with 1-GCG or 3-GIP at the tested doses. Treatment with 2-GLP1 led to body weight loss of $5 \%$ whereas 4-dual-GLP1/GCG, liraglutide or the dual or triple combinations of 1GCG, 2-GLP1 $\pm 3-$ GIP led to 8-9 \% weight loss, all significantly different from vehicle controls and getting close to the weight of lean control mice. Weight loss was driven primarily by an initial decrease in food intake in the first week of treatment which then recovered and remained stable for the rest of the treatment period (figure 1b). Body weight loss predominantly resulted from loss of fat (figure 1c) whereas there was no significant change in lean mass (figure 1d).

Mice with NASH had enlarged livers that had about twice the weight of those of the chow control mice (figure 1e). Whereas treatment with 1-GCG or 3-GIP alone had no effect on liver weight, 2GLP1, the combination of 2-GLP1 with 1-GCG or with 1-GCG and 3-GIP as well as 4-dual-GLP1/GCG and liraglutide led to a significant reduction in liver weight.

As expected, treatment with the glucagon receptor agonist 1-GCG led to an increase in blood glucose whereas it remained constant or decreased in all other treatment groups (figure 1f). Of note, DIONASH mice are not diabetic which explains the limited glucose lowering seen for the GLP1R- or GIPRagonist containing treatment groups.

\section{Liver enzymes, hepatic steatosis and histopathology}

Plasma alanine aminotransferase (ALT) and aspartate aminotransferase (AST) activities were significantly reduced upon intervention with 2-GLP1, the 1-GCG + 2-GLP1 dual combination, the 1GCG + 2-GLP1 + 3-GIP triple combination, 4-dual-GLP1/GCG or liraglutide (figures $2 a$ and $2 b$ ). In the same groups, total liver triglycerides were lower than in vehicle control mice at the end of the treatment period (figure 2c). Notably, there was a significant add-on effect of GCGR and GIPR 
agonism to GLP1R activation in lowering liver triglycerides which was also observed for lowering total liver cholesterol (figure 2d).

Whereas 1-GCG or 3-GIP alone did not lead to a reduction in liver fat content, hepatic steatosis was lower in all treatment groups containing GLP1R-agonistic activity (figure $2 e$ ) with a significantly stronger reduction observed for the 1-GCG + 2-GLP1 + 3-GIP triple combination compared to the GLP1R agonist 2-GLP1 alone. Hepatic galectin-3 as a marker of liver fibrosis was decreased in the dual and triple combination group and upon treatment with 4-dual-GLP1/GCG or liraglutide (figure 2f).

The change in the histological NAFLD activity score (NAS) upon treatment is depicted in figure 3a. In the pre-treatment biopsy, DIO-NASH mice had, on average, a NAS of 6 primarily driven by a steatosis score of 3 in all DIO-NASH animals and an inflammation score of 3 in $85 \%$ of all DIO-NASH mice whereas there was little hepatocyte ballooning (35\% with score 1,65\% with score 0 ) at the onset of therapy. Treatment with 1-GCG, 2-GLP1 $\pm 3-$ GIP dual and triple combinations or the dual GLP1R/GCGR-agonist 4-dual-GLP1/GCG led to a stronger decrease in NAS compared to treatment with single GLP1R-, GCGR- or GIPR-agonistic peptides (figure $3 a$ ) with improvements in all three NAS components steatosis, lobular inflammation and hepatocyte ballooning (not shown). Of note, the dual GLP1/GCG agonist and the dual and triple combination treatments also provided a stronger decrease in NAS compared to liraglutide (figure $3 a$ ) although the amount of body weight loss between these groups was nearly indistinguishable (figure 1a).

The majority of the DIO-NASH mice had a fibrosis score of two in the pre-biopsy. Whereas in the 1GCG and 3-GIP groups only two and one mice, respectively, showed an improvement by one point, about $50 \%$ of animals treated with 2-GLP1, the dual or triple peptide combination or 4-dualGLP1/GCG exhibited a reduction in hepatic fibrosis score by one point (figure $3 b$ ).

This improvement in histology is also reflected in changes in the expression of marker genes for fibrosis (Col1a1, Col3a1, Loxl2) or inflammation (Ccl2, Tlr4). In addition, dermatopontin (Dpt), previously described to be associated with NASH both in rodents and in people ${ }^{23}$ was found to be regulated in DIO-NASH mice and partially normalized upon treatment (figure 4).

\section{Discussion}

Using a mouse model of biopsy-confirmed, diet-induced, advanced NASH with fibrosis, we have demonstrated that combining GLP-1 receptor, glucagon receptor and GIP receptor agonism provides additive effects in improving hepatic steatosis, liver injury and NAFLD activity. 
GLP1R agonists are an established therapy for the treatment of diabetes and obesity $24,25,26,27,28,29,30$, with positive effects on cardiovascular outcome. ${ }^{31,32,33,34,35}$ Recently, dual GLP1R/GCGR ${ }^{14,36}$ and GLP1R/GIPR ${ }^{37}$ have demonstrated clinical proof of concept in lowering body weight and blood glucose in obese patients with type-2 diabetes. Treatment of patients with biopsy-confirmed NASH with the GLP1R agonist liraglutide led to NASH resolution and inhibition of fibrosis progression ${ }^{10}$, and GLP1R agonists were shown to improve hepatic and metabolic health in pre-clinical models of NAFLD or $\mathrm{NASH} .{ }^{38,39,40,41,42,43}$ In contrast, there is little information on the activity of dual or triple agonists in models of $\mathrm{NASH}$, and the contribution of individual incretin or glucagon effects to the combined activity of these molecules has not been systematically investigated. A dual-active peptide targeting GLP1R and GCGR, G49, was described to improve hepatic steatosis and ameliorate liver injury in mice on a methionine and choline-deficient diet and partial hepatectomy. ${ }^{44}$ Likewise, a unimolecular GLP1R/GCGR/GIPR triagonist led to an improvement in steatohepatitis in mice with diet-induced obesity. ${ }^{16}$ However, these studies did not include specific GLP1R or GCGR agonists as comparators to delineate the relative contribution of the two components to the observed effects.

Weight loss is a strong predictor of a reduction in hepatic steatosis and resolution of NASH, independently of whether it is induced by diet and exercise, ${ }^{7}$ bariatric surgery ${ }^{45}$ or pharmacological intervention. ${ }^{10}$ Correspondingly, weight loss observed in our study was tied to improvements in liver metabolism and histology. However, combination of sub-maximal doses of GLP1R and GCGR monoagonists or of GLP1R, GCGR and GIPR mono-agonists as well as administration of a dual GLP1R/GCGR agonist provided a more pronounced improvement in NAFLD activity score compared to a high dose of liraglutide eliciting the maximal GLP1R-mediated response, at the same extent of weight loss. Thus, it is likely that there are additional, weight-independent effects via activation of, e.g., liver GCGR leading to inhibition of hepatic de-novo lipogenesis and stimulation of liver fat utilization. ${ }^{46}$

While providing a first systematic investigation of individual and combined effects of GLP1R-, GIPRand GCGR agonism in diet-induced NASH, our study has certain limitations:

Firstly, peptides could only be tested at one dose because including several doses per mechanism alone and in combination would have made the study excessively large and costly. Individual doses were selected according to previous studies in other murine models to produce small effects on weight and metabolic parameters. However, the selected dose of 2-GLP1 by itself led to significant weight loss, glucose lowering and reduction in hepatic steatosis, leaving less room for additive or synergistic effects of 1-GCG and/or 3-GIP on top of 2-GLP1 to be explored. In further studies, lower doses of 2-GLP1 should be included.

Secondly, development of NASH in our model is driven by a diet artificially high in fat, especially trans-fat, fructose and cholesterol. Whether and how results obtained with this murine model 
translate into clinical efficacy in humans is not clear. In reverse translational studies, several molecules with clinical efficacy in NASH, e.g., obeticholic acid, liraglutide and elafibranor also led to improvements in NASH in our model. ${ }^{42}$ However, it remains to be shown that the model also predicts forward translation into humans. Notably, following an FDA ban on trans-fat as a food component, ${ }^{47}$ the NASH inducing diet has recently been changed to contain palm oil instead of trans-fat. ${ }^{48}$

Finally, it was outside of the scope of our study to further investigate the molecular mechanisms of how GLP1R-, GCGR- or GIPR-specific agonists and their combinations elicit their beneficial effects on systemic metabolism and steatohepatitis, e.g. through comparative expression, proteomics or metabolomics analysis. Such studies are currently under way.

\section{Acknowledgements}

This work was supported by a grant from Agence Nationale pour la Recherche (ANR-16-RHUS-0006PreciNASH).

\section{Conflict of interest}

AK, CK, RE, MB, TH, AE, KL, CR, ZB, JCG, VM and MW are employees of Sanofi, some hold Sanofi shares.

\section{Author contributions}

$A K, J C G, F P, B S, V M$ and $M W$ designed the concept. AK, ANM, CK, RE, CR and ZB performed experiments and analyzed data. MB, TH, KL and MW designed and synthetized test compounds. AK and MW wrote the paper. All authors edited draft versions and approved the final manuscript. 


\section{Table and Figure Legends}

Table 1. Structure, activities and pharmacokinetics of test compounds. (a) Amino acid sequence and modifications of peptides used in this study. (b) In-vitro potencies ( $E C_{50}$ in pM) in HEK293 cells overexpressing the murine GLP1R, GCGR or GIPR for peptides used in this study. Potencies determined for human GLP-1, human glucagon and human GIP are shown for comparison.

Figure 1. (a) Body weight change (\% of day 0 ) throughout the eight-week treatment period. (b) Comparative 24-hour food intake relative to NASH vehicle group. (c) Lean tissue mass, (d) fat tissue mass, and (e) relative liver weight at study termination. (f) Four-hour fasting blood glucose levels after six weeks of treatment. Values are mean of $n=10-12+$ SEM. ${ }^{*} p<0.05 ;{ }^{* *} p<0.01,{ }^{* * *} p<0.001$ compared to NASH Vehicle

Figure 2. (a) Plasma AST, (b) plasma ALT activities at study termination. (c) Liver triglycerides, (d) liver total cholesterol in $\mathrm{mg} / \mathrm{g}$ wet liver tissue at study termination. (e) Hepatic fat content, (f) hepatic galectin-3 content (\% fractional area) as determined by histological quantitative assessment (morphometry). Values are mean of $n=10-12+$ SEM. ${ }^{*} p<0.05 ;{ }^{* *} p<0.01,{ }^{* *} p<0.001$ compared to NASH Vehicle. \#p<0.05, \#\#p<0.01, \#\#\#p<0.001 compared to 2-GLP1 treatment group.

Figure 3. (a) Representative H\&E stained images (20x) of liver morphology at study termination and individual changes in NAFLD activity score (pre- vs. post-treatment) for the different treatment groups. (b) Representative picrosirius red stained images (20x) and individual changes in fibrosis score for the different treatment groups.

Figure 3. Hepatic expression of fibrosis marker genes (a) Col1a1, (b) Col3a1, (c) Loxl2 and (d) Dpt, inflammation marker genes (e) $\mathrm{Ccl} 2$ and (f) TIr7 at study termination as determined by digital droplet PCR. Values are mean of $\mathrm{n}=10-12+\mathrm{SEM} .{ }^{*} \mathrm{p}<0.05 ;{ }^{* *} \mathrm{p}<0.01,{ }^{* * *} \mathrm{p}<0.001$ compared to NASH Vehicle. 
a) Peptide Sequences

\begin{tabular}{|c|c|c|}
\hline Compound & Sequence & $\begin{array}{l}\text { Bid Dose } \\
{[\mu \mathrm{g} / \mathrm{kg}]}\end{array}$ \\
\hline 1-GCG & Tza-s-QGTFTSDYSKQ-K[ $\gamma$ Glu-C16]-ESRRAQEFIEWLLAGGPESGAPPPS-NH ${ }_{2}$ & 20 \\
\hline 2-GLP1 & H-s-EGTFTSDVSKQ-K[ $\gamma$ Glu-C16]-EKRAA-Aib-EFIEWLKNTGPSSGAPPPS-NH ${ }_{2}$ & 3 \\
\hline 3-GIP & Y-a-EGTFISDYSIA-K[ $\gamma$ Glu-C16]-DKIHQQDFVNWLLAQKPSSGAPPPS-NH ${ }_{2}$ & 30 \\
\hline 4-Dual-GLP1/GCG & H-s-QGTFTSDLSKQ-K[ $\gamma$ Glu-C18]-DSRRAGDFIEWLKNGGPSSGAPPPS-NH ${ }_{2}$ & 30 \\
\hline Liraglutide & HAEGTFTSDVSSYLEGQAA-K[ $\gamma$ Glu-C16]-EFIAWLVRGRG-OH & 100 \\
\hline
\end{tabular}

Tza: Thiazolyl-alanine; Aib: 2-Aminoisobutyric acid

b) In vitro receptor agonist potencies (cAMP release) in HEK-293 cell lines stably expressing mouse GLP-1, glucagon or GIP receptors

\begin{tabular}{|l|c|c|c|}
\hline & \multicolumn{3}{|c|}{ mouse EC 50 [pM] } \\
\hline Compound & GLP1R & GCGR & GIPR \\
\hline 1-GCG & 396 & 1.3 & $>10,000$ \\
\hline 2-GLP1 & 1 & $>10,000$ & $>10,000$ \\
\hline 3-GIP & $>10,000$ & $>10,000$ & 3 \\
\hline 4-Dual-GLP1/GCG & 2.3 & 25 & $>10,000$ \\
\hline Liraglutide & 4.4 & $>10,000$ & $>10,000$ \\
\hline & & & $>10,000$ \\
\hline hGLP-1 & 0.9 & 1.3 & 1.2 \\
\hline hGlucagon & 43.5 & & \\
\hline hGIP & & & \\
\hline
\end{tabular}

c) Pharmacokinetic parameters after single subcutaneous administration to female C57BI6 mice

\begin{tabular}{|l|c|c|c|c|}
\hline Compound & $\begin{array}{c}\text { Dose } \\
{[\mathrm{mg} / \mathrm{kg}]}\end{array}$ & $\begin{array}{c}\text { Cmax } \\
{[\mathrm{ng} / \mathrm{ml}]}\end{array}$ & $\begin{array}{c}\text { AUC0-24 } \\
{[\mathrm{ng} \mathrm{h} / \mathrm{ml}]}\end{array}$ & $\begin{array}{c}\mathrm{T1/2} \\
{[\mathrm{h}]}\end{array}$ \\
\hline 1-GCG & 1 & 5640 & 36600 & 2.5 \\
\hline 2-GLP1 & 0.5 & 1820 & 11800 & 3.5 \\
\hline 3-GIP & 0.5 & 5060 & 38200 & 4.1 \\
\hline 4-Dual-GLP1/GCG & 1 & 1930 & 11000 & 3.2 \\
\hline Liraglutide & 1 & 7700 & 79100 & 3.4 \\
\hline
\end{tabular}

\section{Table 1}


(a)

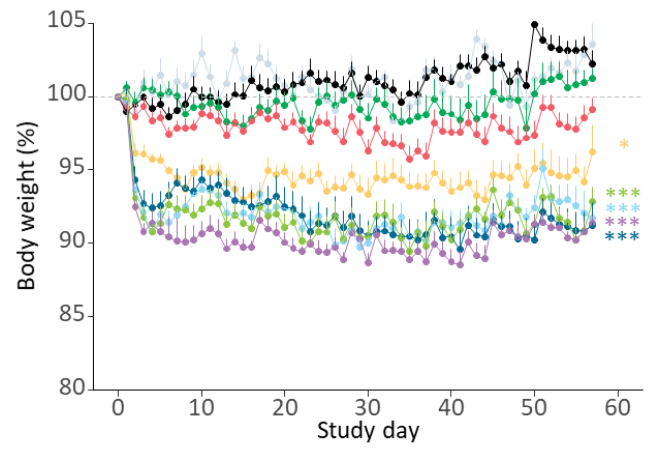

(c)

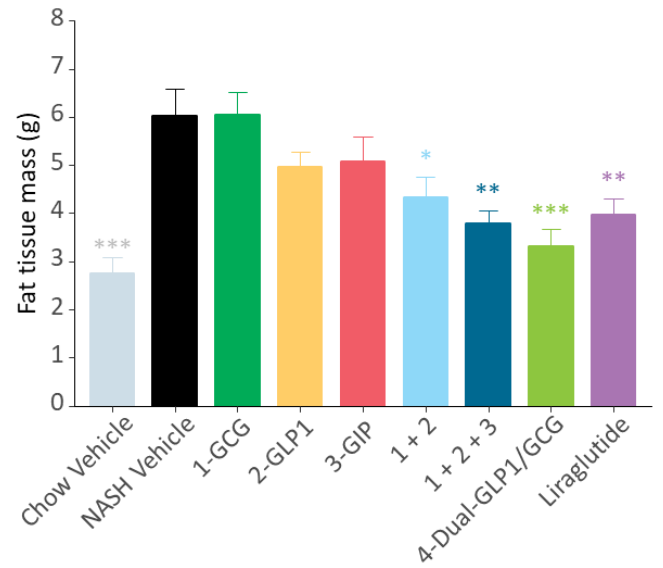

(e)

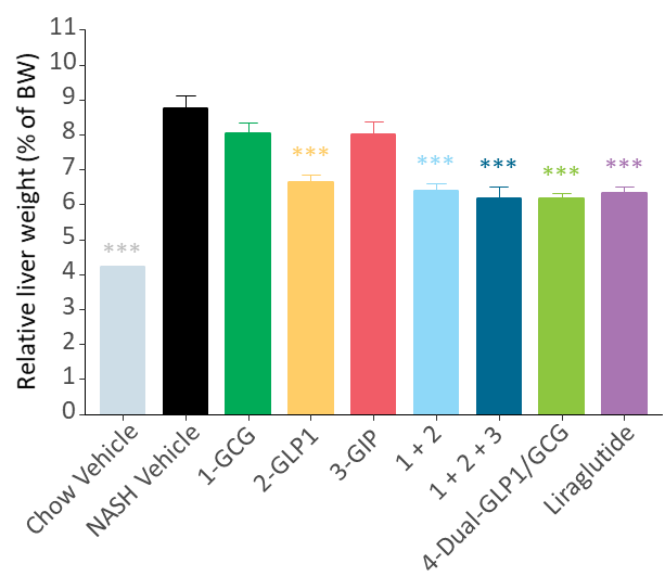

(b)

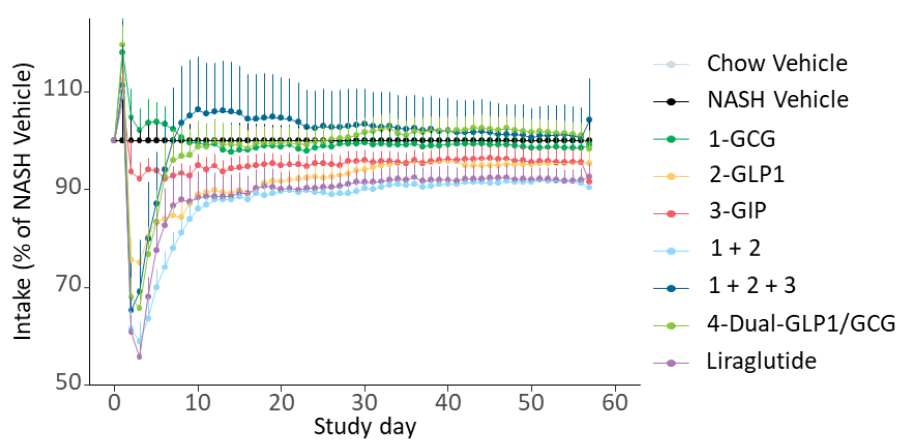

(d)

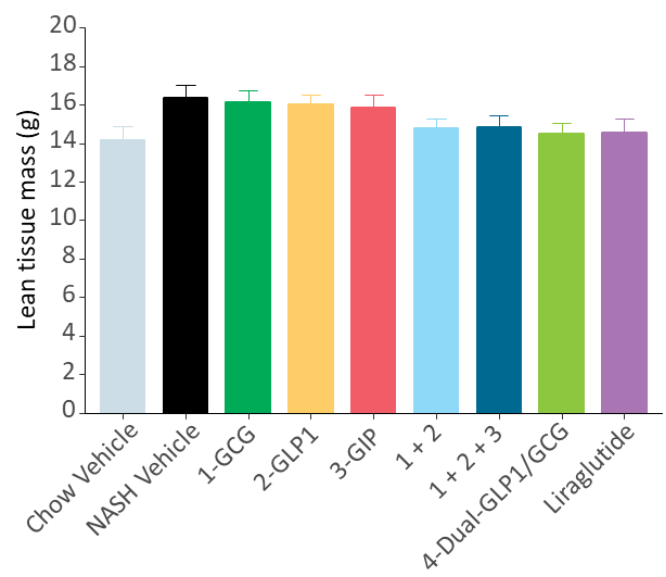

(f)

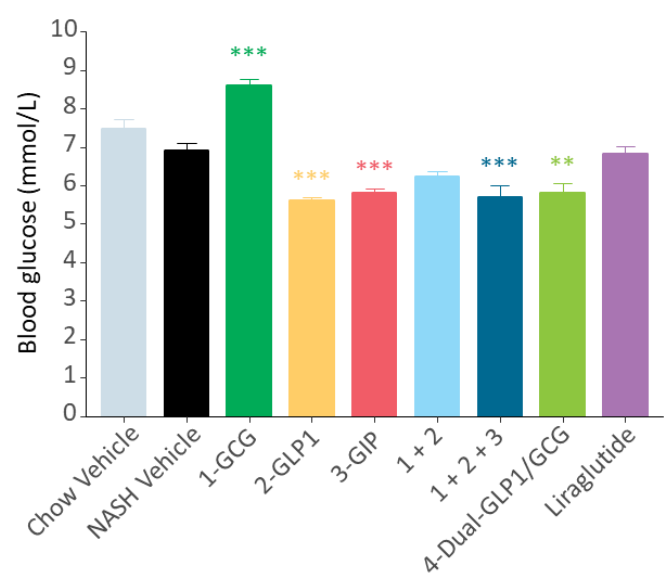

Figure 1 
(a)

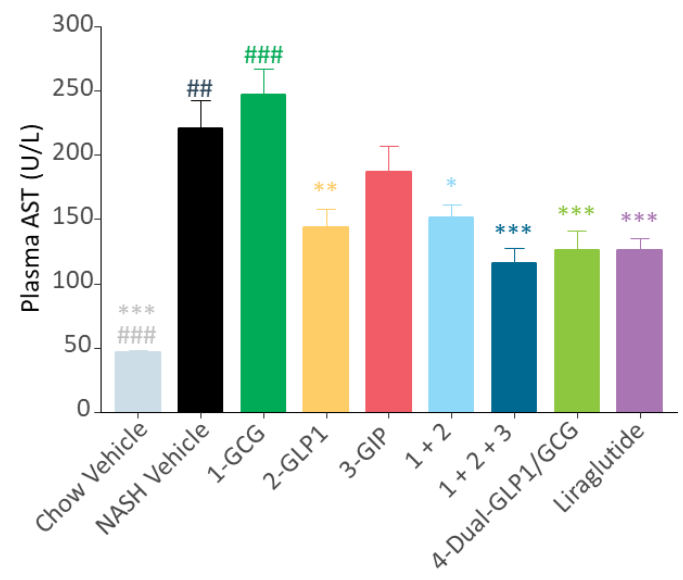

(c)

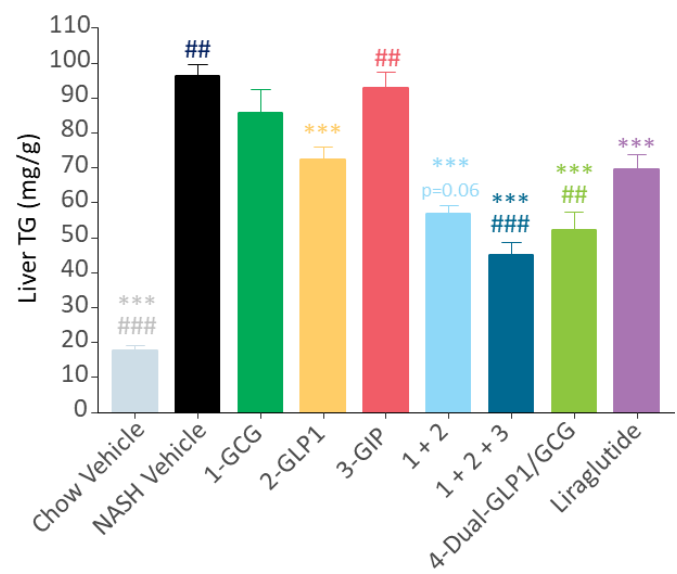

(e)

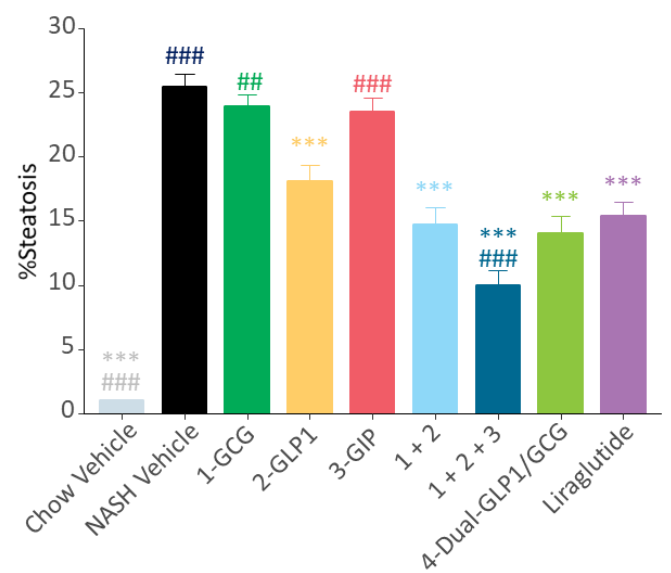

(b)

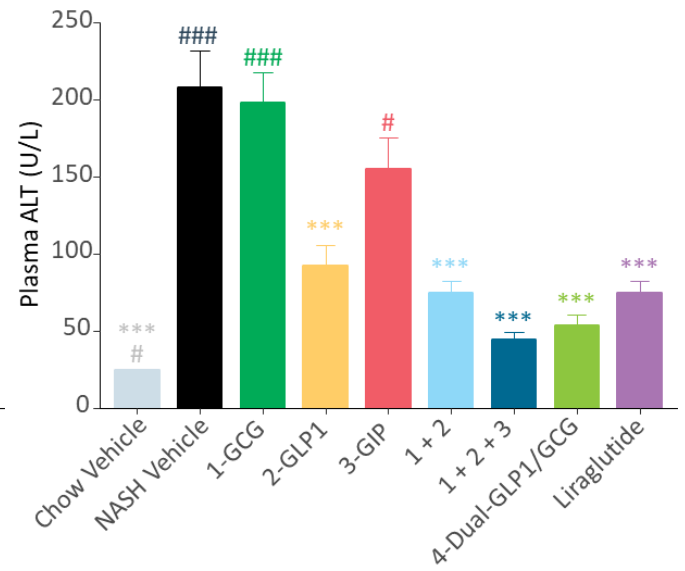

(d)

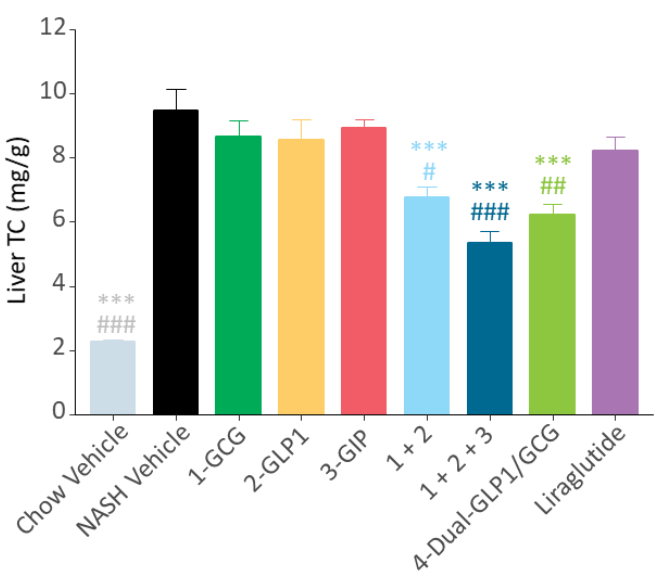

(f)

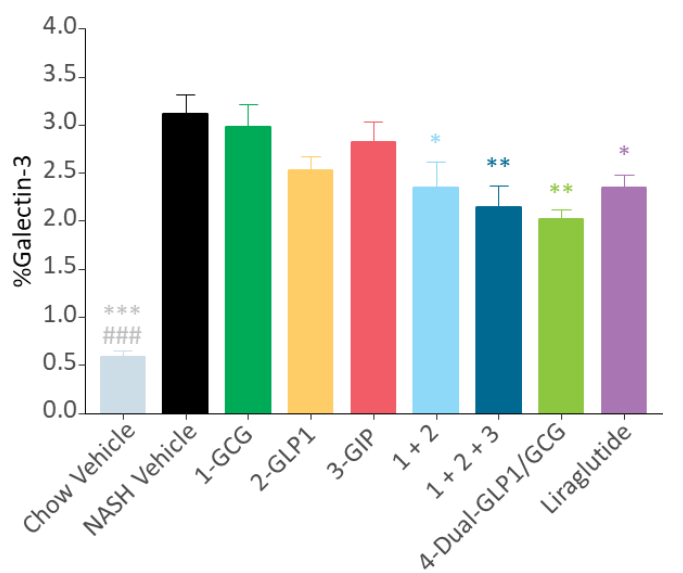

Figure 2 
(a)
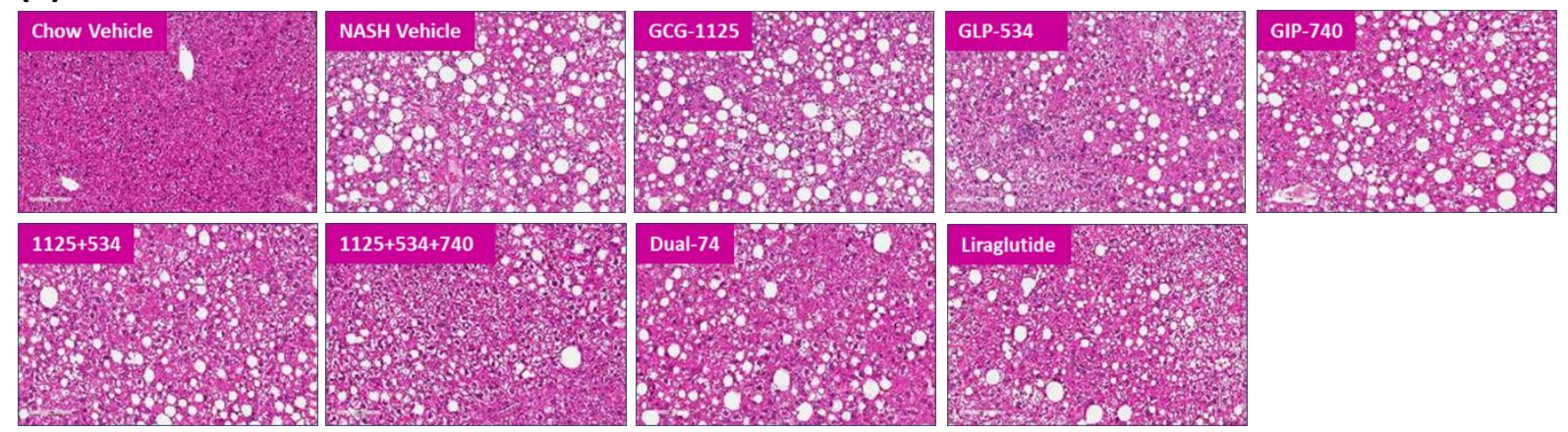

NAFLD Activity Score

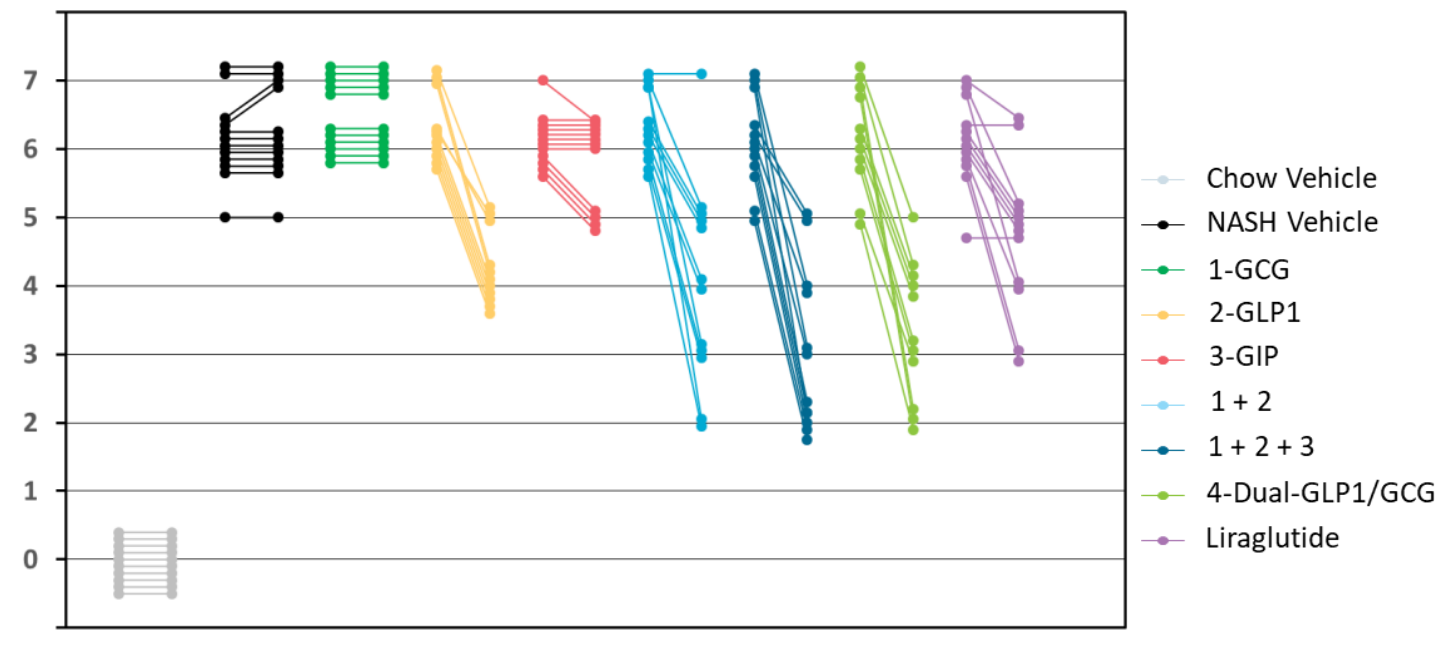

(b)
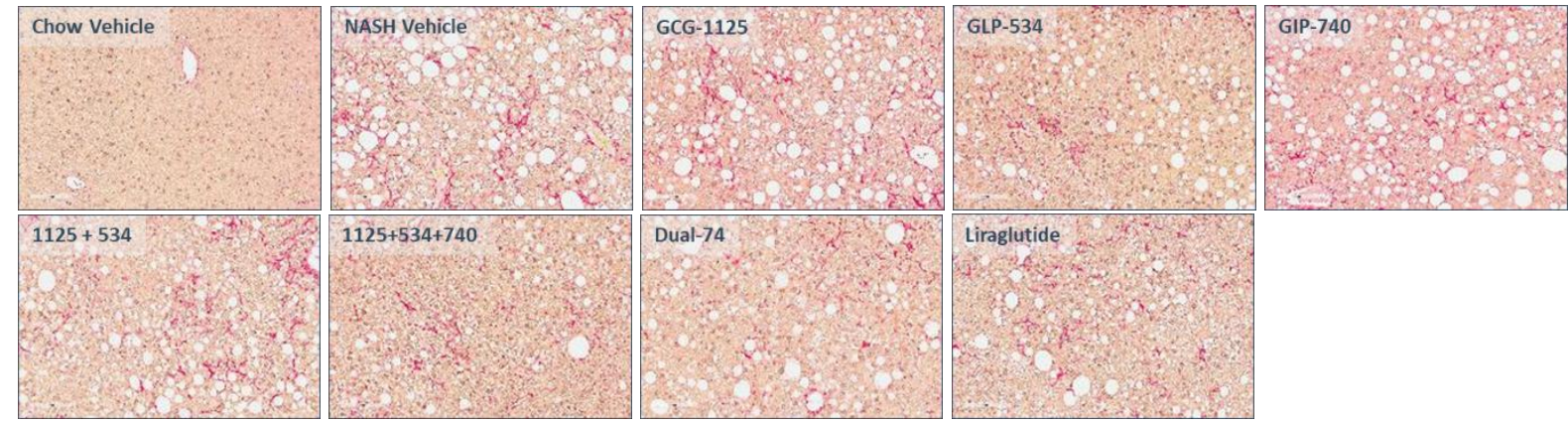

Fibrosis score

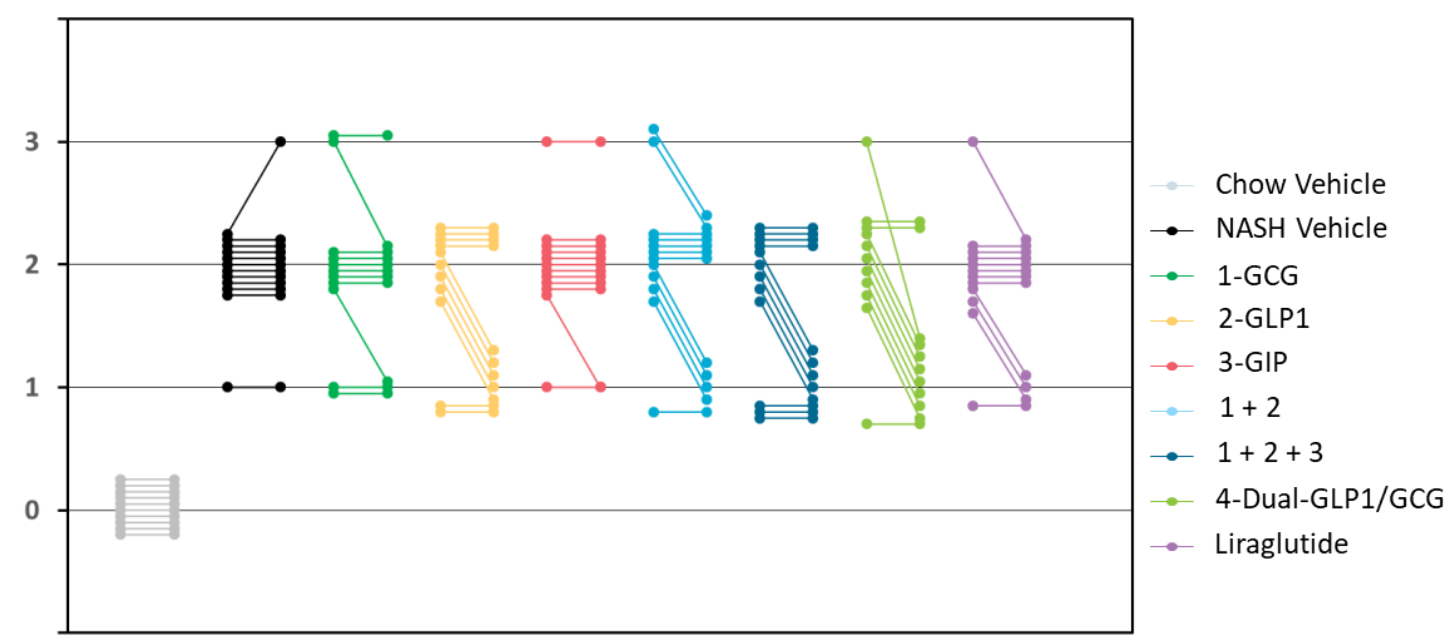

Figure 3 
(a)

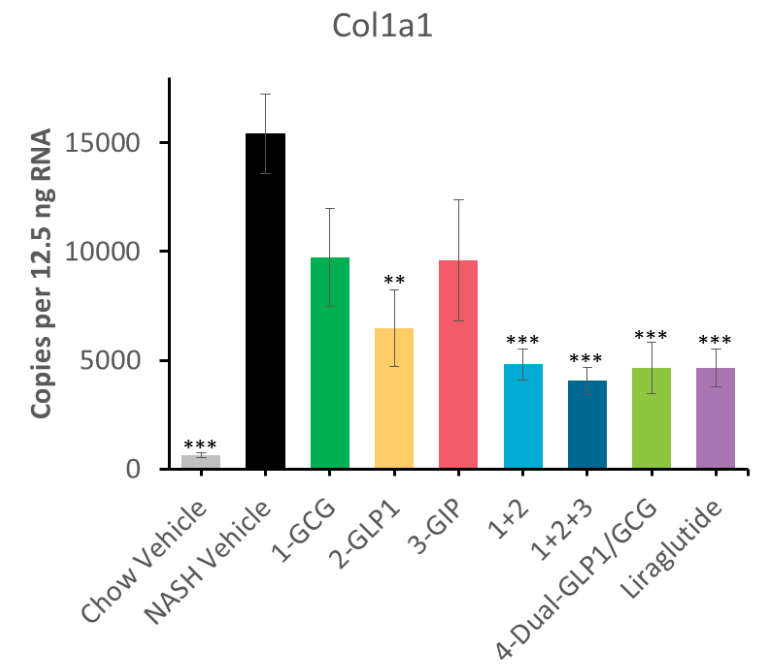

(c)

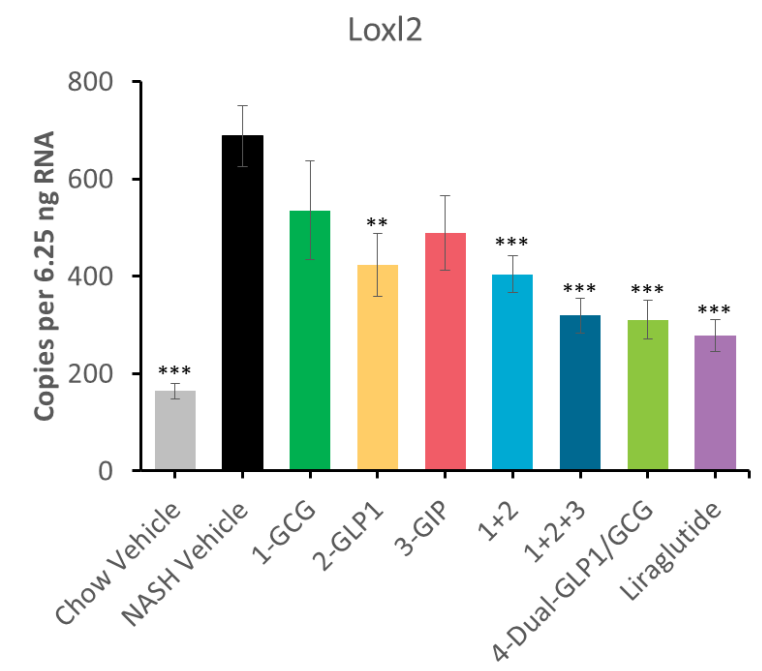

(b)

(d)
Col3a1
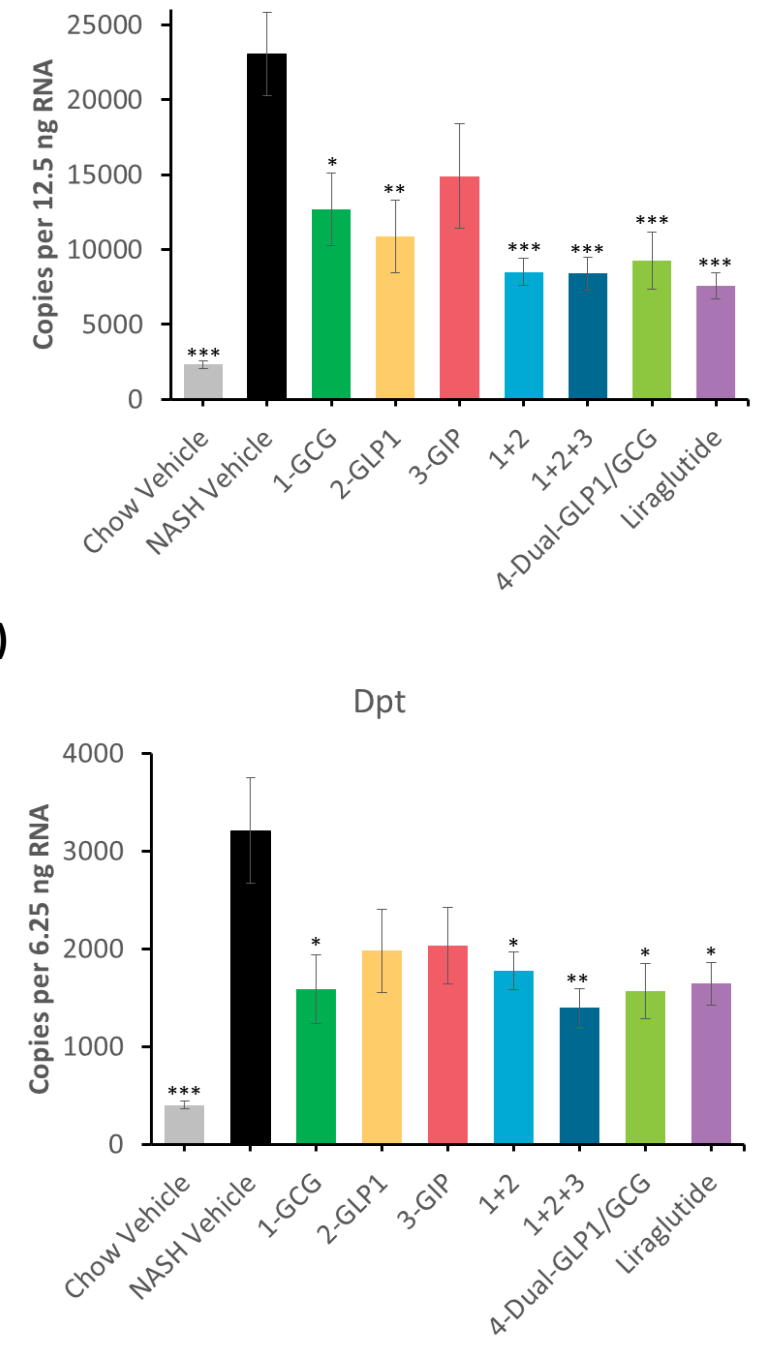

(f)

$\mathrm{Ccl} 2$

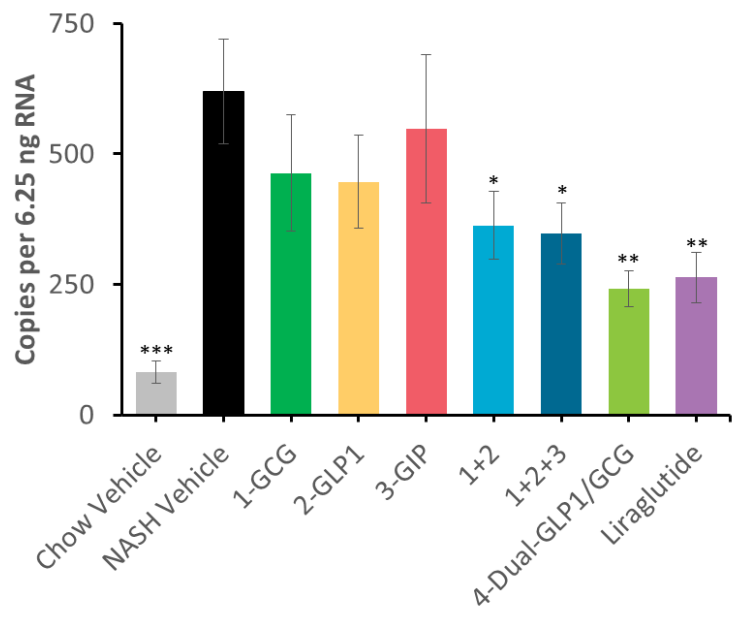

TIr7

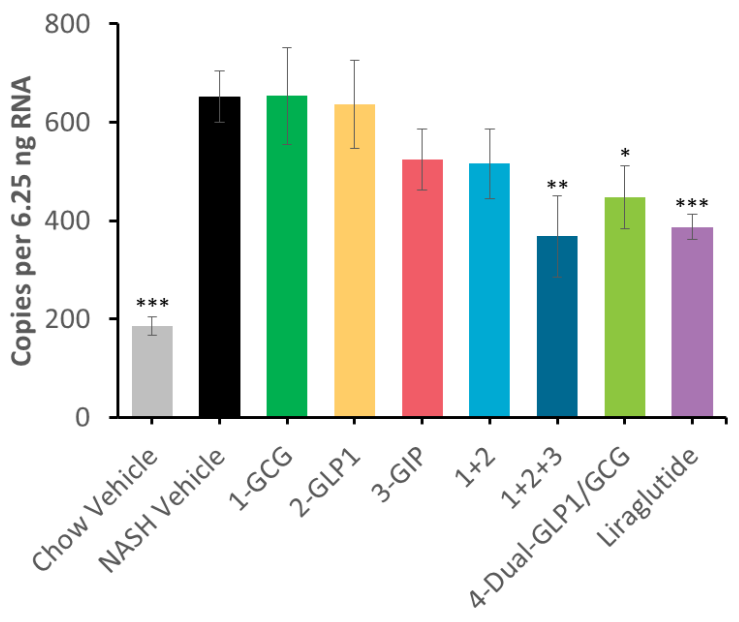

Figure 4 


\section{References}

${ }^{1}$ Younossi ZM, Koenig AB, Abdelatif D, Fazel Y, Henry L, Wymer M. Global epidemiology of nonalcoholic fatty liver disease-Meta-analytic assessment of prevalence, incidence, and outcomes. Hepatol. 2016 64:73-84

${ }^{2}$ Angulo, P., Kleiner, D.E., Dam-Larsen, S., Adams, L.A., Bjornsson, E.S., Charatcharoenwitthaya, P., Mills, P.R., Keach, J.C., Lafferty, H.D., Stahler, A., Haflidadottir, S., and Bendtsen, F. (2015) Liver Fibrosis, but No Other Histologic Features, Is Associated With Long-term Outcomes of Patients With Nonalcoholic Fatty Liver Disease. Gastroenterology, 149 (2), 389-397

${ }^{3}$ Ekstedt, M., Hagström, H., Nasr, P., Fredrikson, M., Stål, P., Kechagias, S., and Hultcrantz, R. Fibrosis stage is the strongest predictor for disease-specific mortality in NAFLD after up to 33 years of followup. Hepatol. 2015 61:1547-1554

${ }^{4}$ Hagström, H., Nasr, P., Ekstedt, M., Hammar, U., Stål, P., Hultcrantz, R., and Kechagias, S. (2017) Fibrosis stage but not NASH predicts mortality and time to development of severe liver disease in biopsy-proven NAFLD. J. Hepatol., 67 (6), 1265-1273

${ }^{5}$ Dulai PS, Singh S, Patel J, Soni M, Prokop LJ, Younossi Z, Sebastiani G, Ekstedt M, Hagstrom H, Nasr P, Stal P, Wong VW, Kechagias S, Hultcrantz R, Loomba R. (2017) Increased risk of mortality by fibrosis stage in nonalcoholic fatty liver disease: Systematic review and meta-analysis. Hepatology. 2017 May;65(5):1557-1565

${ }^{6}$ Wong, R.J., Cheung, R., and Ahmed, A. (2014) Nonalcoholic steatohepatitis is the most rapidly growing indication for liver transplantation in patients with hepatocellular carcinoma in the U.S. Hepatol. Baltim. Md, 59 (6), 2188-2195

${ }^{7}$ Vilar-Gomez E, Martinez-Perez Y, Calzadilla-Bertot L, Torres-Gonzalez A, Gra-Oramas B, GonzalezFabian L, Friedman SL, Diago M, Romero-Gomez M. Weight Loss Through Lifestyle Modification Significantly Reduces Features of Nonalcoholic Steatohepatitis. Gastroenterology. 2015;149:367-78.

${ }^{8}$ Seghieri, M., Christensen, A.S., Andersen, A., Solini, A., Knop, F.K., and Vilsbøll, T. (2018) Future Perspectives on GLP-1 Receptor Agonists and GLP-1/glucagon Receptor Co-agonists in the Treatment of NAFLD. Front. Endocrinol., 9, 649

${ }^{9}$ Investigation of Efficacy and Safety of Three Dose Levels of Subcutaneous Semaglutide Once Daily Versus Placebo in Subjects With Non-alcoholic Steatohepatitis.

https://clinicaltrials.gov/ct2/show/NCT02970942

${ }^{10}$ Armstrong MJ, Gaunt $\mathrm{P}$, Aithal GP, Barton D, Hull D, Parker R, Hazlehurst JM, Guo K; LEAN trial team, Abouda G, Aldersley MA, Stocken D, Gough SC, Tomlinson JW, Brown RM, Hübscher SG, Newsome PN. Liraglutide safety and efficacy in patients with non-alcoholic steatohepatitis (LEAN): a multicentre, double-blind, randomised, placebo-controlled phase 2 study. Lancet 2016;387:679-90

${ }^{11}$ Tschöp, M.H., Finan, B., Clemmensen, C., Gelfanov, V., Perez-Tilve, D., Müller, T.D., and DiMarchi, R.D. (2016) Unimolecular Polypharmacy for Treatment of Diabetes and Obesity. Cell Metab., 24 (1), 51-62

${ }^{12}$ Day JW, Ottaway N, Patterson JT, Gelfanov V, Smiley D, Gidda J, et al. A new glucagon and GLP-1 co-agonist eliminates obesity in rodents. Nat Chem Biol. (2009) 5:749-57

${ }^{13}$ Henderson SJ, Konkar A, Hornigold DC, Trevaskis JL, Jackson R, Fritsch Fredin M, et al. Robust antiobesity and metabolic effects of a dual GLP-1/glucagon receptor peptide agonist in rodents and nonhuman primates. Diab Obes Metab. (2016) 18:1176-90 
${ }^{14}$ Ambery P, Parker VE, Stumvoll M, Posch MG, Heise T, Plum-Moerschel L, Tsai LF, Robertson D, Jain M, Petrone M, Rondinone C, Hirshberg B, Jermutus L. MEDI0382, a GLP-1 and glucagon receptor dual agonist, in obese or overweight patients with type 2 diabetes: a randomised, controlled, doubleblind, ascending dose and phase 2a study. Lancet 2018;391:2607-2618

${ }^{15}$ Finan B, Ma T, Ottaway N, Muller TD, Habegger KM, Heppner KM, et al. Unimolecular dual incretins maximize metabolic benefits in rodents, monkeys, and humans. Sci Transl Med. (2013) 5:209ra151

${ }^{16}$ Jall S, Sachs S, Clemmensen C, Finan B, Neff F, DiMarchi RD, Tschöp MH, Müller TD, Hofmann SM. Monomeric GLP-1/GIP/glucagon triagonism corrects obesity, hepatosteatosis, and dyslipidemia in female mice. Mol Metab 2017;6:440-446

${ }^{17}$ Kristiansen MN, Veidal SS, Rigbolt KT, Tølbøl KS, Roth JD, Jelsing J, Vrang N, Feigh M. Obese dietinduced mouse models of nonalcoholic steatohepatitis-tracking disease by liver biopsy. World J Hepatol. 2016;8:673-84

${ }^{18}$ Clapper JR, Hendricks MD, Gu G, Wittmer C, Dolman CS, Herich J, Athanacio J, Villescaz C, Ghosh SS, Heilig JS, Lowe C, Roth JD. Diet-induced mouse model of fatty liver disease and nonalcoholic steatohepatitis reflecting clinical disease progression and methods of assessment. Am J Physiol Gastrointest Liver Physiol. 2013;305:G483-95

${ }^{19}$ Kleiner DE, Brunt EM, Van Natta M, Behling C, Contos MJ, Cummings OW, Ferrell LD, Liu YC, Torbenson MS, Unalp-Arida A, Yeh M, McCullough AJ, Sanyal AJ; Nonalcoholic Steatohepatitis Clinical Research Network. Design and validation of a histological scoring system for nonalcoholic fatty liver disease. Hepatology 2005;41:1313-21

${ }^{20}$ Evers A, Haack T, Lorenz M, Bossart M, Elvert R, Henkel B, Stengelin S, Kurz M, Glien M, Dudda A, Lorenz K, Kadereit D, Wagner M. Design of Novel Exendin-Based Dual Glucagon-like Peptide 1 (GLP1)/Glucagon Receptor Agonists. J Med Chem 2017;60:5941.

${ }^{21}$ Elvert R, Herling AW, Bossart M, Weiss T, Zhang B, Wenski P, Wandschneider J, Kleutsch S, Butty U, Kannt A, Wagner M, Haack T, Evers A, Dudda A, Lorenz M, Keil S, Larsen PJ. Running on mixed fueldual agonistic approach of GLP-1 and GCG receptors leads to beneficial impact on body weight and blood glucose control: A comparative study between mice and non-human primates. Diabetes Obes Metab 2018;20:1836-1851

${ }^{22}$ Elvert R, Bossart M, Herling AW, Weiss T, Zhang B, Kannt A, Wagner M, Haack T, Evers A, Dudda A, Keil S, Lorenz M, Lorenz K, Riz M, Hennerici W, Larsen PJ. Team Players or Opponents:

Coadministration of Selective Glucagon and GLP-1 Receptor Agonists in Obese Diabetic Monkeys. Endocrinology 2018;159:3105-3119

${ }^{23}$ Lefebvre $P$, Lalloyer $F$, Baugé $E$, Pawlak $M$, Gheeraert $C$, Dehondt $H$, Vanhoutte J, Woitrain $E$, Hennuyer N, Mazuy C, Bobowski-Gérard M, Zummo FP, Derudas B, Driessen A, Hubens G, Vonghia L, Kwanten WJ, Michielsen P, Vanwolleghem T, Eeckhoute J, Verrijken A, Van Gaal L, Francque S, Staels B. Interspecies NASH disease activity whole-genome profiling identifies a fibrogenic role of PPAR $\alpha$ regulated dermatopontin. JCl Insight 2017;2:92264

${ }^{24}$ Pi-Sunyer X, Astrup A, Fujioka K, Greenway F, Halpern A, Krempf M, Lau DC, le Roux CW, Violante Ortiz R, Jensen CB, Wilding JP; SCALE Obesity and Prediabetes NN8022-1839 Study Group. A Randomized, Controlled Trial of $3.0 \mathrm{mg}$ of Liraglutide in Weight Management. N Engl J Med 2015;373:11-22

${ }^{25}$ Blonde L, Russell-Jones D. The safety and efficacy of liraglutide with or without oral antidiabetic drug therapy in type 2 diabetes: an overview of the LEAD 1-5 studies. Diabetes Obes Metab 2009;11 Suppl 3:26-34

${ }^{26}$ Knop FK, Brønden A, Vilsbøll T. Exenatide: pharmacokinetics, clinical use, and future directions. Expert Opin Pharmacother 2017;18:555-571 
${ }^{27}$ Fonseca VA, Alvarado-Ruiz R, Raccah D, Boka G, Miossec P, Gerich JE, EFC6018 GetGoal-Mono Study Investigators. Efficacy and safety of the once-daily GLP-1 receptor agonist lixisenatide in monotherapy: a randomized, double-blind, placebo-controlled trial in patients with type 2 diabetes (GetGoal-Mono). Diabetes Care 2012;35:1225-31.

${ }^{28}$ Umpierrez G, Tofé Povedano S, Pérez Manghi F, Shurzinske L, Pechtner V. Efficacy and safety of dulaglutide monotherapy versus metformin in type 2 diabetes in a randomized controlled trial (AWARD-3). Diabetes Care. 2014;37:2168-76

${ }^{29}$ Nauck MA, Stewart MW, Perkins C, Jones-Leone A, Yang F, Perry C, Reinhardt RR, Rendell M. Efficacy and safety of once-weekly GLP-1 receptor agonist albiglutide (HARMONY 2): 52 week primary endpoint results from a randomised, placebo-controlled trial in patients with type 2 diabetes mellitus inadequately controlled with diet and exercise. Diabetologia 2016;59:266-74.

${ }^{30}$ Ahmann AJ, Capehorn M, Charpentier G, Dotta F, Henkel E, Lingvay I, Holst AG, Annett MP, Aroda VR. Efficacy and Safety of Once-Weekly Semaglutide Versus Exenatide ER in Subjects With Type 2 Diabetes (SUSTAIN 3): A 56-Week, Open-Label, Randomized Clinical Trial. Diabetes Care 2018;41:258266

${ }^{31}$ Marso SP, Daniels GH, Brown-Frandsen K, Kristensen P, Mann JF, Nauck MA, Nissen SE, Pocock S, Poulter NR, Ravn LS, Steinberg WM, Stockner M, Zinman B, Bergenstal RM, Buse JB; LEADER Steering Committee; LEADER Trial Investigators. Liraglutide and Cardiovascular Outcomes in Type 2 Diabetes. N Engl J Med 2016;375:311-22

${ }^{32}$ Marso SP, Bain SC, Consoli A, Eliaschewitz FG, Jódar E, Leiter LA, Lingvay I, Rosenstock J, Seufert J, Warren ML, Woo V, Hansen O, Holst AG, Pettersson J, Vilsbøll T; SUSTAIN-6 Investigators. Semaglutide and Cardiovascular Outcomes in Patients with Type 2 Diabetes. N Engl J Med 2016;375:1834-1844

${ }^{33}$ Hernandez AF, Green JB, Janmohamed S, D'Agostino RB Sr, Granger CB, Jones NP, Leiter LA, Rosenberg AE, Sigmon KN, Somerville MC, Thorpe KM, McMurray JJV, Del Prato S; Harmony Outcomes committees and investigators. Albiglutide and cardiovascular outcomes in patients with type 2 diabetes and cardiovascular disease (Harmony Outcomes): a double-blind, randomised placebo-controlled trial. Lancet. 2018;392:1519-1529

${ }^{34}$ Husain M, Birkenfeld AL, Donsmark M, Dungan K, Eliaschewitz FG, Franco DR, Jeppesen OK, Lingvay I, Mosenzon O, Pedersen SD, Tack CJ, Thomsen M, Vilsb $\varnothing$ II T, Warren ML, Bain SC; PIONEER 6 Investigators. Oral Semaglutide and Cardiovascular Outcomes in Patients with Type 2 Diabetes. $\mathrm{N}$ Engl J Med. 2019;381:841-851

${ }^{35}$ Gerstein HC, Colhoun HM, Dagenais GR, Diaz R, Lakshmanan M, Pais P, Probstfield J, Riesmeyer JS, Riddle MC, Rydén L, Xavier D, Atisso CM, Dyal L, Hall S, Rao-Melacini P, Wong G, Avezum A, Basile J, Chung N, Conget I, Cushman WC, Franek E, Hancu N, Hanefeld M, Holt S, Jansky P, Keltai M, Lanas F, Leiter LA, Lopez-Jaramillo P, Cardona Munoz EG, Pirags V, Pogosova N, Raubenheimer PJ, Shaw JE, Sheu WH, Temelkova-Kurktschiev T; REWIND Investigators. Dulaglutide and cardiovascular outcomes in type 2 diabetes (REWIND): a double-blind, randomised placebo-controlled trial. Lancet 2019;394:121-130

${ }^{36}$ Tillner J, Posch MG, Wagner F, Teichert L, Hijazi Y, Einig C, Keil S, Haack T, Wagner M, Bossart M, Larsen PJ. A novel dual glucagon-like peptide and glucagon receptor agonist SAR425899: Results of randomized, placebo-controlled first-in-human and first-in-patient trials. Diabetes Obes Metab 2019;21:120-128

${ }^{37}$ Frias JP, Nauck MA, Van J, Kutner ME, Cui X, Benson C, Urva S, Gimeno RE, Milicevic Z, Robins D, Haupt A. Efficacy and safety of LY3298176, a novel dual GIP and GLP-1 receptor agonist, in patients with type 2 diabetes: a randomised, placebo-controlled and active comparator-controlled phase 2 trial. Lancet 2018;392:2180-2193 
${ }^{38}$ Trevaskis JL, Griffin PS, Wittmer C, Neuschwander-Tetri BA, Brunt EM, Dolman CS, Erickson MR, Napora J, Parkes DG, Roth JD. Glucagon-like peptide-1 receptor agonism improves metabolic, biochemical, and histopathological indices of nonalcoholic steatohepatitis in mice. Am J Physiol Gastrointest Liver Physiol 2012;302:G762-72.

${ }^{39}$ Daniels SJ, Leeming DJ, Detlefsen S, Bruun MF, Hjuler ST, Henriksen K, Hein P, Karsdal MA, Brockbank S, Cruwys S. Biochemical and histological characterisation of an experimental rodent model of non-alcoholic steatohepatitis - Effects of a peroxisome proliferator-activated receptor gamma (PPAR- $\psi$ ) agonist and a glucagon-like peptide-1 analogue. Biomed Pharmacother 2019;111:926-933

${ }^{40}$ Valdecantos MP, Ruiz L, Pardo V, Castro-Sanchez L, García-Monzón C, Lanzón B, Rupérez J, Barbas C, Naylor J, Trevaskis JL, Grimsby J, Rondinone CM, Valverde ÁM. Differential Effects of a GlucagonLike Peptide 1 Receptor Agonist in Non-Alcoholic Fatty Liver Disease and in Response to Hepatectomy. Sci Rep 2018;8:16461

${ }^{41}$ Ipsen DH, Rolin B, Rakipovski G, Skovsted GF, Madsen A, Kolstrup S, Schou-Pedersen AM, SkatRørdam J, Lykkesfeldt J, Tveden-Nyborg P. Liraglutide Decreases Hepatic Inflammation and Injury in Advanced Lean Non-Alcoholic Steatohepatitis. Basic Clin Pharmacol Toxicol. 2018;123:704-713

${ }^{42}$ Tølbøl KS, Kristiansen MN, Hansen HH, Veidal SS, Rigbolt KT, Gillum MP, Jelsing J, Vrang N, Feigh M. Metabolic and hepatic effects of liraglutide, obeticholic acid and elafibranor in diet-induced obese mouse models of biopsy-confirmed nonalcoholic steatohepatitis. World J Gastroenterol.

2018;24:179-194

${ }^{43}$ Yamamoto T, Nakade Y, Yamauchi T, Kobayashi Y, Ishii N, Ohashi T, Ito K, Sato K, Fukuzawa Y, Yoneda M. Glucagon-like peptide-1 analogue prevents nonalcoholic steatohepatitis in non-obese mice. World J Gastroenterol 2016;22:2512-23

${ }^{44}$ Valdecantos MP, Pardo V, Ruiz L, Castro-Sánchez L, Lanzón B, Fernández-Millán E, García-Monzón C, Arroba Al, González-Rodríguez Á, Escrivá F, Álvarez C, Rupérez FJ, Barbas C, Konkar A, Naylor J, Hornigold D, Santos AD, Bednarek M, Grimsby J, Rondinone CM, Valverde ÁM. A novel glucagon-like peptide $1 /$ glucagon receptor dual agonist improves steatohepatitis and liver regeneration in mice. Hepatology. 2017;65:950-968

${ }^{45}$ Lassailly G, Caiazzo R, Buob D, Pigeyre M, Verkindt H, Labreuche J, Raverdy V, Leteurtre E, Dharancy S, Louvet A, Romon M, Duhamel A, Pattou F, Mathurin P. Bariatric Surgery Reduces Features of Nonalcoholic Steatohepatitis in Morbidly Obese Patients. Gastroenterology. 2015;149:379-88

${ }^{46}$ Müller TD, Finan B, Clemmensen C, DiMarchi RD, Tschöp MH. The New Biology and Pharmacology of Glucagon. Physiol Rev 2017;97:721-766

${ }^{47}$ US Food and Drug Administration, Final Determination Regarding Partially Hydrogenated Oils (Removing Trans Fat). 2018; Available at:

https://www.federalregister.gov/documents/2018/05/21/2018-10714/final-determinationregarding-partially-hydrogenated-oils

${ }^{48}$ Boland ML, Oró D, Tølbøl KS, Thrane ST, Nielsen JC, Cohen TS, Tabor DE, Fernandes F, Tovchigrechko A, Veidal SS, Warrener P, Sellman BR, Jelsing J, Feigh M, Vrang N, Trevaskis JL, Hansen $\mathrm{HH}$. Towards a standard diet-induced and biopsy-confirmed mouse model of non-alcoholic steatohepatitis: Impact of dietary fat source. World J Gastroenterol 2019;25:4904-4920 